\title{
Stress-Related Effects of Low-Intensity Laser Irradiation
}

\author{
Anna V. Deryugina, $\mathrm{PhD}, \mathrm{ScD}^{1}$; Marina N. Ivashchenko, $\mathrm{PhD}^{2 *}$; Pavel S. Ignatyev, $\mathrm{PhD}^{3}$; \\ Tatyana I. Soloveva, $\mathrm{PhD}^{4}$; Evgenia V. Arkhipova ${ }^{4}$; Michael S. Lodyanoy, $\mathrm{PhD}^{2}$; \\ Vladimir A. Petrov²; Aleksandr G. Samodelkin, PhD, ScD ${ }^{2}$ \\ 'Lobachevsky State University of Nizhny Novgorod, Nizhny Novgorod, Russia \\ ${ }^{2}$ Nizhny Novgorod State Agricultural Academy, Nizhny Novgorod, Russia \\ ${ }^{3}$ Production Association «Urals Optical \& Mechanical Plant» named after E.S. Yalamov, Ekaterinburg, Russia \\ ${ }^{4}$ Privolzhsky Research Medical University, Nizhny Novgorod, Russia
}

\begin{abstract}
The purpose of this study was to investigate the effect of low-level laser (light) therapy (LLLT) on the electrokinetic properties of red blood cells (RBCs), taking into account the activity of stress-realizing systems of the body. The RBC electrophoretic mobility (RBCEM) was used as an index of stress reaction. The experiment included two series: in vivo and in vitro. Analyzing the LLLT effect on RBCEM, we can assume that the body's response to LLLT is associated with a short-term activation of the sympathoadrenal system and the subsequent longer reaction of the hypothalamic-pituitary-adrenal axis. Through activation of the hypothalamic-pituitary-adrenal axis, LLLT can indirectly cause the development of adaptation processes in the body. (International Journal of Biomedicine. 2019;9(2):163-167.)
\end{abstract}

Key Words: low-level laser (light) therapy $\bullet$ stress $\bullet$ red blood cells $\bullet$ electrophoretic mobility of red blood cells

\section{Introduction}

A growing number of reports have shown a positive outcome for low-level laser (light) therapy (LLLT), sometimes known as photobiomodulation, in restorative and rehabilitative medicine. Although the exact mechanisms are yet to be fully understood, LLLT has been used to rescue neurons from neurotoxic injuries ${ }^{(1-3)}$ and help tissue repair and wound healing in animal models. ${ }^{(4-8)}$ LLLT is effective in pain relief and promotes the recovery of some pathologies, including tendinopathies, osteoarthritis, wound healing, and nerve injuries. ${ }^{(9-15)}$

The fundamental mechanism of photobiomodulation ${ }^{(16)}$ is proposed to involve mitochondria as the primary cellular target for the photons leading to increased cytochrome $\mathrm{C}$ oxidase activity, ${ }^{(17)}$ release of nitric oxide, ${ }^{(18,19)}$ and an increase in ATP levels. ${ }^{(20)}$ Changes in intracellular signaling molecules, such as calcium ions, reactive oxygen species and redox sensitive

*Corresponding author: Marina N. Ivashchenko, PhD; Nizhny Novgorod State Agricultural Academy, Nizhny Novgorod, Russia.E-mail: kafedra2577@mail.ru transcription factors, like NF- $\mathrm{B}$, are also thought to mediate the effects of light. ${ }^{(21,22)}$ Low-level lasers have been reported to attenuate oxidative stress. ${ }^{(23,24)}$

LLLT at low doses has been shown to enhance cell proliferation of fibroblasts, keratinocytes, endothelial cells, and lymphocytes. ${ }^{(25-30)}$ The mechanism of proliferation is thought to result from photo-stimulation of the mitochondria leading to activation of signaling pathways and up regulation of transcription factors, eventually giving rise to increases in growth factors. ${ }^{(31)}$ It has been observed in many studies that LLLT exhibits a biphasic dose response curve, ${ }^{(32,33)}$ whereby lower doses of light are more effective than much higher doses.

Although LLLT is mostly applied to localized diseases, and its effect is often considered to be restricted to the irradiated area, there are reports of systemic effects of LLLT acting at a site distant from the illumination. ${ }^{(34-36)}$

The purpose of this study was to investigate the effect of LLLT on the electrokinetic properties of red blood cells (RBCs), taking into account the activity of stress-realizing systems of the body. Of particular interest were RBCs, due to their participation in processes related to maintaining homeostasis at the level of the whole body. 


\section{Materials and Methods}

The experiment included two series: in vivo and in vitro. The first series of the experiment was carried out on 75 non-pedigree female rats at 3.5-4 months of age weighing $200 \pm 20 \mathrm{~g}$. The animals were divided into 5 equal groups. Group 1 (control group) included intact animals $(n=15)$. Animals of Group $2(n=15)$ were treated with LLLT. For stress modeling, the animals of Group 3 received $(n=15)$ a single intraperitoneal injection of adrenaline hydrochloride solution $(0.1 \mathrm{mg} / \mathrm{kg})$, and animals of Group $4(\mathrm{n}=15)$ received an intraperitoneal cortisol solution $(0.4 \mathrm{mg} / \mathrm{kg})$. The animals of Group $5(\mathrm{n}=15)$ received a single intraperitoneal injection of physiological saline solution.

Animals of Group 2 were given transcutaneous LLLT at the occipital region for 10 minutes. The laser irradiation parameters: a pulse regime, $800-900 \mathrm{~nm}$ wavelength, pulse repetition frequency of $415 \mathrm{~Hz}$. The minimum value of average power density in the plane of the output window was $193 \mu \mathrm{W} / \mathrm{cm}^{2}$. Blood samples were taken from the sublingual vein in $15 \mathrm{~min}, 30 \mathrm{~min}, 60 \mathrm{~min}$, and $120 \mathrm{~min}$ after starting the experiment.

The second series of the experiments in vitro was performed on the isolated RBCs. Blood samples were taken from the sublingual vein of the animals. The effect of stress factors was studied in experiments (20 experiments in each case) in vitro using washed erythrocytes. RBCs were incubated with adrenaline $\left(1 \times 10^{-9} \mathrm{~g} / \mathrm{ml}\right.$ and $\left.1 \times 10^{-10} \mathrm{~g} / \mathrm{ml}\right)$ or cortisol $\left(5 \times 10^{-7} \mathrm{~g} / \mathrm{ml}\right)$, or they were treated with LLLT (for 10 minutes at $2-5 \mathrm{~mm}$ from the applicators). The controls for experiments with LLLT were intact cells, for experiments with adrenaline and cortisol - cells incubated with physiological saline solution.

In order to modify the cell structure, RBCs were fixed with glutaraldehyde according to Walter and Krob. ${ }^{(37)}$ The erythrocyte suspension was incubated with $0.1 \%$ glutaraldehyde solution at $22-24^{\circ} \mathrm{C}$ for $10 \mathrm{~min}$. After a triple washing in salt solution, RBCs were incubated with adrenaline/cortisol or they were treated with LLLT.

The RBC electrophoretic mobility (RBCEM) was used as an index of stress reaction. The RBCEM level was measured by the microelectrophoresis method using a cytopherometer in our modification by registering the $100 \mu \mathrm{m}$ RBC transmission time in Tris-HCL buffer with $\mathrm{pH}$ of 7.4 and amperage of $12 \mathrm{MA}$. The RBC electrophoretic mobility value was defined using the formula: $\mathrm{U}=\mathrm{S} / \mathrm{T} \times \mathrm{H}$, where $\mathrm{S}-$ a distance to which the cells moved, $\mathrm{T}$ - time, $\mathrm{H}$ - a gradient of electric potential. The value of potential gradient was determined using the formula: $\mathrm{H}=\mathrm{I} / \mathrm{g} \times \chi$, where $\mathrm{I}-$ amperage, $\mathrm{g}$ - chamber cross section, $\chi-$ electrical conductivity of the media. ${ }^{(38,39)}$

Animals were housed in keeping with the rules for good laboratory practice. Experiment was performed in accordance with the Guide for the Care and Use of Laboratory Animals (the institute of Laboratory Animal Resources, 1996) and with approval of local Ethics Committee.

Statistical analysis was performed using the statistical software «Statistica». (v6.0, StatSoft, USA). The ShapiroWilk test was used in testing for normality. Baseline characteristics were summarized as frequencies and percentages for categorical variables and as mean \pm SEM for continuous variables. Student's unpaired t-test was used to compare two groups for data with normal distribution. Differences of continuous variables departing from the normal distribution, even after transformation, were tested by the Mann-Whitney $U$-test. A value of $P<0.05$ was considered statistically significant.

\section{Results and Discussion}

The results obtained by the first series of the experiment are represented in Table 1. LLLT provoked a decrease in the level of RBCEM 15 minutes after the beginning of the experiment, and it was increased by the 120 th minute by $10 \%$ relative to the control group value. It is known that LLLT acts on the body at the cell and systemic levels. We may suppose that the development of a typical stress reaction is a response to LLLT at the systemic levels. Given that the sympathoadrenal system and hypothalamic-pituitary-adrenal (HPA) axis are central stress response systems, we analyzed the effects of adrenaline and cortisol. Thus, the intraperitoneal injections of adrenaline provoked a decrease in the RBCEM level during all the experiment, making $74 \%$ of the value of the control group at the last registration point (120the $\mathrm{min}$ ). On the contrary, the cortisol injection provoked an increase in the RBCEM level at all the observation points.

Table 1.

The RBCEM level $\left(\mu \mathrm{m} \mathrm{cm} \mathrm{B} \mathrm{B}^{-1} \mathrm{~s}^{-1}\right)$ during the first series of the experiment in vivo

\begin{tabular}{|l|c|c|c|c|}
\hline \multirow{2}{*}{ Group } & \multicolumn{4}{|c|}{ Period after the beginning of the experiment (min) } \\
\cline { 2 - 5 } & 15 & 30 & 60 & 120 \\
\hline Group 3 & $1.02 \pm 0.09^{*}$ & $1.05 \pm 0.06^{*}$ & $0.99 \pm 0.08^{*}$ & $0.92 \pm 0.08^{*}$ \\
\hline Group 4 & $1.28 \pm 0.08^{*}$ & $1.49 \pm 0.05^{*}$ & $1.73 \pm 0.05^{*}$ & $1.67 \pm 0.09^{*}$ \\
\hline Group 5 & $1.17 \pm 0.02$ & $1.19 \pm 0.02$ & $1.19 \pm 0.02$ & $1.23 \pm 0.04$ \\
\hline Group 2 & $0.96 \pm 0.02^{*}$ & $0.98 \pm 0.04$ & $1.08 \pm 0.02$ & $1.12 \pm 0.02^{*}$ \\
\hline Group 1 & $1.02 \pm 0.02$ & $1.00 \pm 0.03$ & $1.04 \pm 0.02$ & $1.02 \pm 0.02$ \\
\hline
\end{tabular}

${ }^{*} P<0.05$ - with animals receiving physiological saline solution (Group 5).

A registered primary decrease in the RBCEM index under stressful effects may be mediated by an increase in the level of circulating catecholamines in the blood and/or an increase in the sensitivity of cell adrenoreceptors to them. It is known that in reactions to stress, the concentration of adrenaline in the blood plasma increases tenfold in a few minutes. In the stress reaction, catecholamines, by activating the release of ACTH, stimulate an increase in the blood of the adrenal hormone level. While catecholamines reflect the onset of an immediate trigger effect, corticosteroids have a long-lasting effect. ${ }^{(40)}$ Under stress, the blood content of corticosterone in rats increases after 30 minutes and reaches a maximum after 2 hours. Probably, the excretion of corticosteroids, aimed at limiting the first phase of the stress reaction, determines the increase in the RBCEM index (the second phase). Analyzing the LLLT effect on RBCEM, we can assume that the body's 
response to LLLT is associated with a short-term activation of the sympathoadrenal system and the subsequent longer reaction of the HPA axis. Through activation of the HPA axis, LLLT can indirectly cause the development of adaptation processes in the body.

Based on this point, the effect of LLLT at the cellular level can also be realized through the consequent starting of processes mediated by the influence of changing concentrations of catecholamines and corticosteroids in the peripheral blood.

In the experiments in vitro, we found that LLLT provoked a decrease in the RBCEM index by $20 \%(P<0.05)$ by the 15 th minute after the beginning of the experiment, but after that, the RBCEM index increased considerably and reached $188 \%$ of intact cell value by the end of the experiment. The incubation of RBCs with adrenaline in a concentration corresponding to its concentration in the blood under the conditions of the physiological norm $\left(1 \times 10^{-10} \mathrm{~g} / \mathrm{ml}\right)$ did not cause changes in the RBCEM level. Concentrations corresponding to the level during stress reactions $\left(1 \times 10^{-9} \mathrm{~g} / \mathrm{ml}\right)$ provoked an irreversible decrease in RBCEM $(P<0.05)$. In contrast to the experiments with epinephrine, the incubation with cortisol $\left(5 \times 10^{-7} \mathrm{~g} / \mathrm{ml}\right)$ led to increasing RBCEM in the range from 30 minutes to 2 hours (Table 2).

Table 2.

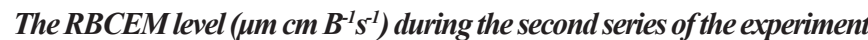
in vitro

\begin{tabular}{|c|c|c|c|c|c|}
\hline \multirow{2}{*}{ Group } & \multirow{2}{*}{$\begin{array}{l}\text { Before the } \\
\text { beginning } \\
\text { of the ex- } \\
\text { periment }\end{array}$} & \multicolumn{4}{|c|}{ Period after the beginning of the experiment } \\
\hline & & 15 & 30 & 60 & 120 \\
\hline Group 2 & $1.26 \pm 0.08$ & $0.92 \pm 0.09$ & $1.55 \pm 0.18^{*}$ & $1.30 \pm 0.18$ & $2.06 \pm 0.20^{*}$ \\
\hline Group 1 & $1.26 \pm 0.08$ & $1.15 \pm 0.10$ & $0.96 \pm 0.07$ & $1.09 \pm 0.12$ & $1.09 \pm 0.10$ \\
\hline $\begin{array}{l}\text { Group } 3 \\
\text { (AHS: } \\
\left.1 \times 10^{-9} \mathrm{~g} / \mathrm{ml}\right)\end{array}$ & $1.32 \pm 0.02$ & $1.24 \pm 0.05$ & $1.19 \pm 0.08^{*}$ & $1.15 \pm 0.07^{*}$ & $1.14 \pm 0.05^{*}$ \\
\hline $\begin{array}{l}\text { Group } 3 \\
\text { (AHS: } \\
\left.1 \times 10^{-10} \mathrm{~g} / \mathrm{ml}\right)\end{array}$ & $1.25 \pm 0.07$ & $1.10 \pm 0.11$ & $0.94 \pm 0.08$ & $1.1 \pm 0.12$ & $1.05 \pm 0.07$ \\
\hline $\begin{array}{l}\text { Group } 4 \\
\text { (CS: } \\
\left.5 \times 10^{-7} \mathrm{~g} / \mathrm{ml}\right)\end{array}$ & $1.32 \pm 0.02$ & $1.52 \pm 0.06$ & $1.96 \pm 0.06^{*}$ & $1.72 \pm 0.08^{*}$ & $1.72 \pm 0.08^{*}$ \\
\hline Group 5 & $1.32 \pm 0.02$ & $1.33 \pm 0.02$ & $1.36 \pm 0.06$ & $1.32 \pm 0.06$ & $1.35 \pm 0.04$ \\
\hline
\end{tabular}

AHS - adrenaline hydrochloride solution; CS - cortisol solution; ${ }^{*} P<0.05$ - with intact animals (Group 1).

Thus, the change in RBCEM under the effect of LLLT on isolated RBCs has the same typical picture as when it affects the whole body. The first reaction of RBCEM, reflecting a decrease in the total charge of the erythrocyte membrane, is comparable to the change in RBCEM under the adrenaline action. The second phase (an increase in RBCEM) is similar to the changes in RBCEM detected for cortisol.

Thus, the detected changes in RBCEM under LLLT in vitro experiments are consistent with in vivo experiments and associated with changes in the electrokinetic properties of RBCs in stress response, which can be realized through a modification of the receptor apparatus of cells. Taking into account that the most important structural components of this apparatus are proteins, we may conclude that they are a target for stress factors. Thus, one of the likely effects of LLLT action is associated with a nonspecific effect on biopolymers, which leads to a change in the charge of proteins, in their conformational structure, and in their functional state. ${ }^{(41)}$

To confirm the role of proteins in modifying the activity of cellular receptors, we conducted experiments with pretreatment of RBCs with glutaraldehyde fixing protein molecules due to the formation of cross-links in -NH2-groups. ${ }^{(37)}$ It was shown that pretreatment of RBCs with glutaraldehyde practically nullified the first phase of the reaction of intact erythrocytes to the stress effects of LLLT and epinephrine. At the same time, in the series with cortisol, it was found that the phase of increased RBCEM detected in previous experiments was preserved (Table 3 ).

Table 3.

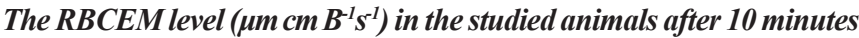
of glutaraldehyde fixation

\begin{tabular}{|l|c|c|c|c|}
\hline \multicolumn{1}{c|}{$\begin{array}{c}\text { Kind of } \\
\text { influence }\end{array}$} & \multicolumn{4}{|c|}{ Period after the influence (min) } \\
\hline & 15 & 30 & 60 & 120 \\
\hline LLLT & $1.64 \pm 0.10^{*}$ & $1.88 \pm 0.08^{*}$ & $1.53 \pm 0.11^{*}$ & $1.55 \pm 0.09^{*}$ \\
\hline Cortisol & $1.36 \pm 0.05$ & $1.67 \pm 0.12^{*}$ & $1.68 \pm 0.10^{*}$ & $1.65 \pm 0.08^{*}$ \\
\hline Adrenaline & $1.32 \pm 0.06$ & $1.36 \pm 0.10$ & $1.39 \pm 0.08$ & $1.44 \pm 0.10$ \\
\hline
\end{tabular}

${ }^{*} P<0.05$ with the $R B C E M$ index of the glutaraldehyde fixed $R B C$ value $\left(1.38 \pm 0.06 \mu \mathrm{m} \mathrm{cm} B^{-1} \mathrm{~s}^{-1}\right)$.

The results of the study indicate that, against the background of the fixation of protein molecules by glutaraldehyde, the reaction of dropping RBCEM in response to stress is nullified. It can be argued that the mechanism of cell response is realized in the same way and is associated with changes in cell receptor responsiveness. At the same time, if the first phase of the response reaction is associated with modification of membrane adrenoreceptors, the second phase may be due to the modification of intracellular steroid receptors located in the cytosol. Apparently, the effect of LLLI in vitro experiments is determined by the possibility of its influence on the hormonal stress-realizing components of the cell. At the same time, the first phase can be considered as an "anxiety stage" of the system, arising by the mechanism of excitation of the sympathoadrenal regulation with an increasing adrenaline effect on the cell membranes. The second stage of stress response is characterized by the return of a reduced function to the initial state, or an increased function of the system in new conditions, which may be one of the mechanisms of LLLT action.

\section{Competing Interests}

The authors declare that they have no competing interests.

\section{Sources of Funding}

This study was supported by the Russian Foundation for Basic Research, research project No. 18-016-00195. 


\section{References}

1. Wong-Riley MT, Liang HL, Eells JT, Chance B, Henry MM, Buchmann E, et al. Photobiomodulation directly benefits primary neurons functionally inactivated by toxins: role of cytochrome C oxidase. J Biol Chem. 2005;280(6):4761-71.

2. Liang HL, Whelan HT, Eells JT, Wong-Riley MT. Nearinfrared light via light-emitting diode treatment is therapeutic against rotenone- and 1-methyl-4-phenylpyridinium ioninduced neurotoxicity. Neuroscience. 2008;153(4):963-74. doi: 10.1016/j.neuroscience.2008.03.042.

3. Wang CZ, Chen YJ, Wang YH, Yeh ML, Huang MH, Ho $\mathrm{ML}$, et al. Low-level laser irradiation improves functional recovery and nerve regeneration in sciatic nerve crush rat injury model. PLoS One. 2014;9(8):e103348. doi: 10.1371/ journal.pone.0103348. eCollection 2014.

4. Albertini R, Villaverde AB, Aimbire F, Salgado MA, Bjordal JM, Alves LP, et al. Anti-inflammatory effects of lowlevel laser therapy (LLLT) with two different red wavelengths (660 $\mathrm{nm}$ and $684 \mathrm{~nm}$ ) in carrageenan-induced rat paw edema. J Photochem Photobiol B. 2007;89(1):50-5.

5. Draper WE, Schubert TA, Clemmons RM, Milse SA. Low-level laser therapy reduces time to ambulation in dogs after hemilaminectomy: a preliminary study. J Small Anim Pract. 2012;53(8):465-9.

6. Gigo-Benato D, Geuna S, de Castro Rodrigues A, Tos P, Fornaro M, Boux E, et al. Low-power laser biostimulation enhances nerve repair after end-to-side neurorrhaphy: a double-blind randomized study in the rat median nerve model. Lasers Med Sci. 2004;19(1):57-65.

7. Casalechi HL, Leal-Junior EC, Xavier M, Silva JA Jr, de Carvalho Pde T, Aimbire F, Albertini R. Low-level laser therapy in experimental model of collagenaseinduced tendinitis in rats: effects in acute and chronic inflammatory phases. Lasers Med. Sci. 2013;28(3):989-95.

8. Gigo-Benato D, Russo TL, Tanaka EH, Assis L, Salvini TF, Parizotto NA. Effects of 660 and $780 \mathrm{~nm}$ low-level laser therapy on neuromuscular recovery after crush injury in rat sciatic nerve. Lasers Surg Med. 2010;42:673-82.

9. Chow RT, Johnson M, Lopes-Martins RA, Bjordal JM. Efficacy of low-level laser therapy in the management of neck pain: a systematic review and meta-analysis of randomised placebo or active-treatment controlled trials. Lancet. 2009;374(9705):1897-908.

10. Brosseau L, Robinson V, Wells G, Debie R, Gam A, Harman K, et al. Low level laser therapy (Classes I, II and III) for treating rheumatoid arthritis. Cochrane Database Syst Rev. 2005; 19:CD002049.

11. Tumilty S, Munn J, McDonough S, Hurley DA, Basford JR, Baxter GD. Low level laser treatment of tendinopathy: a systematic review with meta-analysis. Photomed Laser Surg. 2010;28(1):3-16.

12. Marcos RL,Arnold G, Magnenet V, Rahouadj R, Magdalou J, Lopes-Martins RÁ. Biomechanical and biochemical protective effect of low-level laser therapy for Achilles tendinitis. J Mech Behav Biomed Mater. 2014;29:272-85.

13. Kheshie AR, Alayat MS, Ali MM. High-intensity versus low-level laser therapy in the treatment of patient with knee osteoarthritis: a randomized controlled trial. Lasers Med Sci. 2014;29(4):1371-6.

14. Saber K, Chiniforush N, Shahabi S. The effect of low level laser therapy on pain reduction after third molar surgery. Minerva Stomatol. 2012;61(7-8): 319-22.
15. Alves AC, Vieira R, Leal-Junior E, dos Santos S, Ligeiro AP, Albertini R, et al. Effect of low-level laser therapy on the expression of inflammatory mediators and on neutrophils and macrophages in acute joint inflammation. Arthritis Res Ther. 2013;15(5):116.

16. Chung H, Dai T, Sharma SK, Huang YY, Carroll JD, Hamblin MR. The nuts and bolts of low-level laser (light) therapy. Ann Biomed Eng. 2012;40(2):516-33. doi: 10.1007/ s10439-011-0454-7.

17. Wong-Riley MT, Liang HL, Eells JT, Chance B, Henry MM, Buchmann E, et al. Photobiomodulation directly benefits primary neurons functionally inactivated by toxins: role of cytochrome c oxidase. J Biol Chem. 2005;280(6):4761-71.

18. Karu TI, Pyatibrat LV, Afanasyeva NI. Cellular effects of low power laser therapy can be mediated by nitric oxide. Lasers Surg Med. 2005;36(4):307-14.

19. Moriyama Y, Nguyen J, Akens M, Moriyama EH, Lilge L. In vivo effects of low level laser therapy on inducible nitric oxide synthase. Lasers Surg Med. 2009; 41(3):227-31.

20. Passarella S, Casamassima E, Molinari S, Pastore D, Quagliariello E, Catalano IM, Cingolani A. Increase of proton electrochemical potential and ATP synthesis in rat liver mitochondria irradiated in vitro by helium-neon laser. FEBS Lett. 1984;175(1):95-9.

21. Chen AC, Arany PR, Huang YY, Tomkinson EM, Sharma SK, Kharkwal GB, et al. Low-level laser therapy activates NF-kB via generation of reactive oxygen species in mouse embryonic fibroblasts. PLoS One. 2011;6(7):e22453. doi: 10.1371/journal.pone.0022453.

22. Lavi R, Shainberg A, Friedmann H, Shneyvays V, Rickover O, Eichler M, et al. Low energy visible light induces reactive oxygen species generation and stimulates an increase of intracellular calcium concentration in cardiac cells. J Biol Chem. 2003;278(42):40917-22.

23. Giuliani A, Lorenzini L, Gallamini M, Massella A, Giardino L, Calzà L. Low infra red laser light irradiation on cultured neural cells: effects on mitochondria and cell viability after oxidative stress. BMC Complement Altern Med. 2009;9:8. doi: 10.1186/1472-6882-9-8.

24. Huang YY, Nagata K, Tedford CE, McCarthy T, Hamblin MR. Low-level laser therapy (LLLT) reduces oxidative stress in primary cortical neurons in vitro. J Biophotonics. 2013;6(10):829-38. doi: 10.1002/jbio.201200157.

25. AlGhamdi KM, Kumar A, Moussa NA. Low-level laser therapy: a useful technique for enhancing the proliferation of various cultured cells. Lasers Med. Sci. 2012;27:237-49.

26. Lubart R, Wollman Y, Friedmann H, Rochkind S, Laulicht I. Effects of visible and near infrared lasers on cell cultures. J Photochem Photobiol B. 1992;12(3):305-10.

27. Frigo L, Fávero GM, Lima HJ, Maria DA, Bjordal JM, Joensen J, et al. Low-level laser irradiation (InGaAlP-660 $\mathrm{nm}$ ) increases fibroblast cell proliferation and reduces cell death in a dose-dependent manner. Photomed Laser Surg. 2010;28(Suppl 1):S151-6.

28. Basso FG, Oliveira CF, Kurachi C, Hebling J, Costa CA. Biostimulatory effect of low-level laser therapy on keratinocytes in vitro. Lasers Med Sci. 2013;28(2):367-74. 29. Szymanska J, Goralczyk K, Klawe JJ, Lukowicz M, Michalska M, Goralczyk B, et al. Phototherapy with lowlevel laser influences the proliferation of endothelial cells and vascular endothelial growth factor and transforming growth factor-beta secretion. J Physiol Pharmacol. 2013;64(3):387-91. 30. Agaiby AD, Ghali LR, Wilson R, Dyson M. 
Laser modulation of angiogenic factor production by T-lymphocytes. Lasers Surg Med. 2000;26(4):357-63.

31. Saygun I, Nizam N, Ural AU, Serdar MA, Avcu F, Tözüm TF. Low-level laser irradiation affects the release of basic fibroblast growth factor (bFGF), insulin-like growth factor-I (IGF-I), and receptor of IGF-I (IGFBP3) from osteoblasts. Photomed Laser Surg. 2012;30(3):149-54.

32. Huang YY, Chen AC, Carroll JD, Hamblin MR. Biphasic dose response in low level light therapy. Dose Response. 2009;7(4):358-83.

33. Huang YY, Sharma SK, Carroll J, Hamblin MR. Biphasic dose response in low level light therapy - an update. Dose Response. 2011;9(4):602-18.

34. Rochkind S1, Rousso M, Nissan M, Villarreal M, Barr-Nea L, Rees DG. Systemic effects of low-power laser irradiation on the peripheral and central nervous system, cutaneous wounds, and burns. Lasers Surg Med. 1989;9(2):174-82.

35. Coelho RC, Zerbinati LP, de Oliveira MG, Weber JB. Systemic effects of LLLT on bone repair around PLLA-PGA screws in the rabbit tibia. Lasers Med Sci. 2014;29(2):703-8. 36. Schindl A, Heinze G, Schindl M, Pernerstorfer-Schön $\mathrm{H}$, Schindl L. Systemic effects of low-intensity laser irradiation on skin microcirculation in patients with diabetic microangiopathy. Microvasc Res. 2002;64(2):240-6.

37. Walter H, Krob EJ. Fixation with even small guantities of glutaraldehyde effects red bloods cell surface properties in a cell. Biosci Rep.1989;9(6):727-35.

38. Deryugina AV, Shumilova AV, Filippenko ES, Galkina YV, Simutis IS, Boyarinov GA. Functional and biochemical parameters of erythrocytes during mexicor treatment in posttraumatic period after experimental blood loss and combined traumatic brain injury. Bull Exp Biol Med. 2017;164(1):26-9. doi: 10.1007/s10517-017-3918-4.

39. Deryugina AV, Ivashchenko MN, Ignatyev PS, Zolotova MV, Samodelkin AG. Electrophoretic Mobility of Red Blood Cells and Micronucleus Test in Exfoliated Buccal Cells as Stress Intensity Markers. International Journal of Biomedicine. 2018;8(4):347-50.

40. Sunada, Rao BS, Raju TR. Restraint stress-induced alterations in the levels of biogenic amines, amino acids and AchE activity in the hippocampus. Neurochem Res. 2000;25(12):1547-52.

41. Deryugina AV, Samodelkin AG, Ivashchenko MN, Ignatyev PS, Zolotova MV. The use of low intensity laser therapy for the reduction of technology stress of cows. AERAdvances in Engineering Research. 2018:151;820-24. 